\title{
The Future Relevancy of University Institutions' Teaching in the Digital Era
}

\author{
Nitza Davidovitch, Beni Reuven Levy \\ Ariel University, Ariel, Israel \\ Email: d.nitza@ariel.ac.il, benirl@ariel.ac.il
}

How to cite this paper: Davidovitch, N., \& Levy, B. R. (2017). The Future Relevancy of University Institutions' Teaching in at the Digital Era. Creative Education, 8, 953-974. https://doi.org/10.4236/ce.2017.86070

Received: April 7, 2017

Accepted: May 28, 2017

Published: May 31, 2017

Copyright $\odot 2017$ by authors and Scientific Research Publishing Inc. This work is licensed under the Creative Commons Attribution International License (CC BY 4.0).

http://creativecommons.org/licenses/by/4.0/ (c) (i) Open Access

\begin{abstract}
The paper focuses on the structured and well-planned design and execution of courses in academic studies in general, and in architecture in particular, based on the great relevance of the learning-centered approach for teaching in universities in the digital era, related to the traditional teaching-centered approach applied in the majority of academic institutions today. The design of a course according to the learning-centered approach has unique value, particularly in the information era, with computers virtually and instantaneously transmitting endless knowledge. In the learning-centered approach, unlike frontal transfer of information, a dialogue is formed between academic faculty and students, leading to compatibility between learning outcomes (course goals) and teaching methods. stressing the value of course design according to the learning-centered approach are necessary as a result of social, cultural, and technological changes in the current information highway era and the consequent status of knowledge as possessed by everyone, while noting and emphasizing the special needs involved in the challenges of teaching and learning in this era. The paper also depicts the significance of recording learning outcomes, and the benefits and challenges associated with the formulation of learning goals. To illustrate this topic, development of a course in the "backward design" method, consistent with the learning-centered paradigm, shall be presented. The challenges of this method shall also be portrayed, with the possibility of generalization to varied disciplines. This paper shall emphasize the main potential advantage of physical academic institutions and universities, where students and teachers meet, talk, and hold direct and unmediated discussions, and through the learning-centered approach, versus the virtual knowledge and teaching centers have recently emerged as an alternative to traditional academic institutions and are seemingly threatening to obviate the justification for universities. It is particularly important also, in light of disturbing data indicating a considerable drop in university registration rates, in Israel and elsewhere, with the current young generation finding gradually less interest in universities as capable of shaping their personal and professional future. Therefore,
\end{abstract}


with the gradual increase in accessible knowledge, instructors are required to bring with them added value to the teaching process. This is a complicated requirement that compels instructors to relinquish traditional teaching patterns. Planning a course in this method requires extensive forethought, time, and effort, compared to designing a course following the traditional method. To promote such added-value teaching, the academic system needs a model that recognizes, appreciates, and compensates faculty for the efforts they invest in learning-centered teaching, and one that will incentivize instructors to devote time and energy to developing, revising, and improving their teaching practice to develop these aspects in their work. Such a model also serves the existential interests of the institutions of higher education, in their role as entities that also responsible for properly training future generations, in an era when traditional teaching methods being no longer sufficient, attractive, or meeting the needs and wishes of potential students for shaping their personal and professional future, in light of the paradigmatic changes in knowledge acquisition.

\section{Keywords}

Teaching, Learning Outcomes, Knowledge, Varied Disciplines

\section{1. "What Will We Get Out of It?" - Academic Studies: What for? On Motivation for Acquiring Higher Education from the Students' Perspective}

In the professional literature, some researchers cite extrinsic motives (such as career and income) while others cite intrinsic motives stemming from the studies themselves (interest, comprehension) (Dippelhofer-Hayden \& Carpenter, 1990; Dippelhofer-Steim, Bargel, Bromberek, Jetten, Kump, Sagmeister, \& Walter, 1984). Greene and Minton (1989) in the US enumerate educational, professional, and career seeking motives. Windolf (1995) in Germany indicates career aspirations (high income, professional promotion, prestige, and security); interest in science - in scientific research, scientific theories, insight into the studied field; life style considerations - the wish to experience the student environment, a "moratorium" to plan for the future, and motives of social rectification - interest in social improvement, political activity, and affecting change, helping others. Canny (1995) includes an employment element - preparation for a career, obtaining a good job; an academic element - intellectual development, expanding one's education; and a social element - meeting people, having a good time, access to athletic facilities. In the Israeli context, Shapira and Etzioni-Halevy (1973) distinguished between educational motives - perceiving studies as a goal, instrumental motives - training for a profession and professional or social advancement, and social motives - the possibility of leading a social life. Doron (1983) lists seven motives: studies, career, self fulfillment, family, personal professional advancement, earning a living, social life.

Thus, in different countries at different times, similar motives were found, some 
intrinsic and some extrinsic. In this study we shall focus on three types of motives:

\section{Intrinsic motives:}

1) Inquiry-oriented motives - to acquire knowledge, expand horizons, clarify values and outlooks, enhance self understanding.

2) Motives related to self fulfillment - the need for achievement, motivation to learn, and realizing inclinations and skills.

\section{Extrinsic motives:}

3) Instrumental motives - to acquire a profession, earn a degree and a diploma, develop a career, and increase one's income.

Intrinsic motives are associated with one's internal motivation. By studying, individuals managing to fulfill their need for achievement, the achievement motive is defined as the urge to succeed and to cope with challenges set by oneself. This is a motive that urges one to reach high achievements in a certain field based on a sense of gratification, fulfillment, and challenge. Anyone motivated by a high achievement need sets a certain challenge and strives to perform the related task (at school, at work, and in other fields) as best as possible, in order to receive the sense of satisfaction that stems from overcoming barriers and achieving goals. All people have, to some degree, a motive that urges them to reach achievements. The difference between them is in the degree to which one is ready to make an effort on behalf of the goals set. People with high achievement needs are ready to invest time and efforts and to persist in them in order to realize their goals, while those with low achievement needs invest less time and effort, are less persistent in their efforts, and tend to retreat when encountering failure (Bar-El \& Nuemayer, 1996). At present, it is accepted that the achievement motive is affected by environmental processes, mainly how one was educated as a child. As children, people with high achievement needs had parents who encouraged them and supported them even when they failed.

Another motive is the motivation to learn and its association with academic achievements. The literature has many definitions of academic motivation from which we shall bring two: Bar-El \& Nuemayer (1996) - the achievement motive is defined as the urge to make an effort and to succeed in one's goals. This motive, which urges one to reach high achievements in any field, is manifested in achievement-oriented behavior characterized by: greater choice of challenging tasks, expectations of success, hard work, persistence over time, increasing efforts when encountering failure, and greater willingness to take calculated risks.

Motivation to achieve is a most efficient measure for predicting academic success, when in some cases motivation to achieve is more predictive of success than intelligence (Cassidy \& Lynn, 1991). Many studies deal with the question of which factors affect motivation, particularly motivation for academic achievements. Studies indicate that different motives cause students to learn, for instance: choice of the study material, degree of effort and persistence required, and preferring a certain study method. Bar-El \& Nuemayer (1996) brings two factors: intrinsic, such as motivation based on pleasure, stemming from mere performance of the behavior; and external, such as rewards and penalties. Fur- 
thermore, some study only in order to satisfy their social need (need for belonging and love), the need for inquisitiveness, for self-fulfillment, for achievement, etc.

Extrinsic motives are associated with the instrumental dimension of shaping one's personal future. By studying people acquire a profession, receive a diploma that helps them enter the labor market and increase their income. Credentialism was defined by Dore (1976) as an emphasis given by the student or the employer. The inclination to attribute excessive significance to the diploma rather than to the skills themselves creates a type of magic circle that requires one to earn more advanced degrees in an attempt to compensate for the reduced value of the diploma. This process occurs mainly due to employers' presumption that education "improves" workers and that they are receiving more for their money when they employ a person with a more advanced degree than normally required. This presumption has led employers to require their workers to have a Bachelor's and Master's degree, a phenomenon termed "credentialism" by Brown (2001). Tyler (1982) claims that, according to the human capital theory, employers use credentialism as a classifying element that they see as a type of predictor of workers' efficiency and productivity. Education is perceived as a factor that increases one's productivity as well as the state's indirect profits. This conception sees intellectuals as human capital, linking level of education to financial reward and well-being (Amaral \& Magaihaes, 2004). Brown (2001) explains this trend and says that in the bureaucratic world, credentialism provides information on the individual's ability to perform tasks according to the required bureaucracy. In the labor market, holding an academic degree represents something else that is more significant, such as knowledge, skills, loyalty, etc. According to this explanation, the market requires the degrees as these are perceived as essential for assessing the worker's skills, even if they are not necessary for the job. The fact that academic degrees, of all things, became a measure of one's ability is explained by Bills (2014), who says that academic degrees became a type of employment asset. Traditionally, students see the acquisition of a profession and the earning of a diploma as a way of increasing their economic profits. The Bachelor's degree is perceived by workers as a future economic profit. Wonacott (2000) says that “... Bachelor's degree is widely considered the universal ticket to a desirable, high-paying career and comfortable middleclass life" (p. 1), and all the more so the Master's degree. While employers use academic degrees to distribute jobs, employees see them as a way of increasing their personal profit. Indeed, the research supports this approach that perceives education as a way of achieving economic security and a defense against poverty (Vernon, 2010; Vedder, 2011).

One's motives for studying indeed set a general direction for one's choice of study track, but the specific choice depends on several factors, including the support of family and friends, personal resources, and academic achievements.

\section{About the Field of Architecture and Architectural Studies at the Ariel University School of Architecture}

Architecture is the discipline of creating place, from an ethical, scientific, and ar- 
tistic approach, in a cultural, social, environmental, and technological context. Architect, "chief builder", is the person responsible for all design and construction works, beginning from the abstract idea and ending with the final details of its realization in the public and private space. The word for architect in Hebrew is adrichal, or ardichal, derives from the Akkadian word erad-ekaly which means "servant of the temple", a person that serves in the holy place, that is responsible for the quality of life within the place created. The School of Architecture at Ariel University emphasizes the significance of combining both these qualities in the personality and training of students of architecture and as a basis for their public responsibility for the environment and society and towards becoming architects committed to a sustainable and inspiring creation.

The School of Architecture at Ariel University maintains a vibrant, energetic, and involved environment, a place of meaningful, innovative, original, rich, and relevant architectural thinking and work. The school, as a place that turns thoughts into verbal, visual, and material expression, is unique for its emphasis on a wide Israeli identity, as the unique Israeli architectural contribution to the global, regional, and local environment.

The activities of the school, its aspirations and products, are the outcomes of an entire relationship based on the fundamental values of personal and professional ethics, an ecological approach to the natural and constructed environment, professionalism with wide horizons stemming from the command of customary tools as well as from new tools developed from the essence of concrete work, social solidarity, mutual assistance and caring for others, and striving for an aesthetics with both internal and external beauty.

The school is committed to training and nurturing its students and teachers towards excellence, while promoting them according to clear criteria of classification, examination, and choice, and it encourages this academic and professional progress. The school's graduates are trained to be creative people, independent thinking and capable of teamwork, professionals who respect the profession and have good command of its intricacies, with social and environmental sensitivity and responsibility, a sense of mission, involved, influential, and promoting a good, health, varied, challenging, and high quality life environment. The multicultural human diversity of the school's students and teachers, who come from all parts of the country, from the periphery and the center, and from all social levels, inspires the worldview of all school personnel and enhances their unmediated learning and the pluralistic nature of the place.

The school's teaching staff encompasses both a professional and a multidisciplinary academic body. It includes architects from the field, theoreticians, academic researchers and historians, various experts from specific professional fields and from the supplementary fields of engineering, natural sciences, humanities, and social sciences. The skilled and cohesive faculty consists of experienced teachers with the necessary extensive professional knowledge and proper human relations. The School of Architecture is characterized by the involvement of studio teachers in theoretical and technological subjects as well, multidiscip- 
linary involvement that enables constant updating of contents between the different study settings, whether for extra support if necessary or for the concentration of study disciplines and layers, while coordinating expectations, assignments, and schedules. This also enables overall supervision of the students' professional development as individuals.

The course of studies aims to train the school's graduates for the challenges they will encounter as architects in the twenty first century, including relevant updated theoretical, academic, and professional knowledge, work methods and practices, and proficiency in architectural and urban planning and design. The program is intended to open for graduates a perspective to past and present cultures - both eastern and western - to expand their education, enhance their knowledge, develop a critical approach, receive updates, and prepare for changes in society, in the environment, and in the architectural discipline, both in theory and in practice.

Studies in the studio are the heart of the school's learning and production, with studies based on personal instruction in the tradition of a "master" who guides the student through the paths of the architectural discipline. Accordingly, most of the studies consist of discourse and dialogue between the instructor and the student and among the students themselves. Studies are mainly personal, with collaboration, where the instructor's role is to talk to the students, listen to them, criticize their work, and guide it. Students are supposed to practice the architectural work in the studio, simulating reality, and thus gradually internalize architecture's manners of thinking and practice, throughout their years of study. The theoretical and practical general curriculum is supposed to provide support and the knowledge platform necessary for research, practice, and creation in the studio. At present, the nature of studies in the studio can serve as inspiration for learning-centered teaching in other architecture courses as well as in other academic disciplines.

As part of the enrichment of the school's study environment, beyond the classroom and recent technological means, an upgraded workshop is available to the school's students for building models and learning about construction materials and processes, while experiencing actual processes as part of the studio, design, technology, and ecology provided by the school. The workshop is equipped with machinery and mechanical, electrical, pneumatic, and manual tools and is adapted for use with the various construction materials, while emphasizing use of recycled and environmentally friendly materials. The model workshop operates side by side with an ecological architecture laboratory, as part of architectural education with ecological responsibility. The lab is equipped with professional literature, samples of elements and construction materials customary in architectural practice, and an archive of students' projects from the technological studio and the ecological studio. The service yard adjacent to the workshop makes it possible to build large models as well, even building ecological houses from recycled materials on a 1:1 ratio, houses that operate independently using alternative energy sources. 
Another important study space operated by the school is the interdisciplinary and extracurricular setting available to students and teachers, in which varied learning activities take place: Ariel University's School of Architecture is the first of Israel's architecture schools to hold a structured and consecutive series of lectures by local and foreign guests aimed at enriching students' theoretical knowledge and exposing them to the academic, professional, and interdisciplinary environment. This activity takes place as part of the school seminar intended for all the school's teachers and students, which also includes a lecture series by the school's teachers on varying annual topics, supervised by the head of the school. These lectures arouse constant discussion and discourse among the school's teachers and students in order to clarify the message and uniqueness of the school and of its human components. In addition, school study days and symposiums are also held within and outside the school.

The school also holds successive annual seminars in various locations abroad, which are an important part of its tradition of study. The primary goal of this seminar is to widen students' horizons, enrich and enhance their body of knowledge, and advance their academic and professional abilities, through research, observation, impressions, documentation, recording, and encounters with leading academic and practical personnel at the destination. This study activity also contributes to promoting the involvement of the school and its students within the global environment and to reinforcing their academic ties in the world. Every summer there is also a travelling academic seminar in Israel, aimed mainly at enhancing knowledge of Israel's various regions, forming direct contact with different areas and towns in Israel and with their residents and local leaders, research, documentation, and planning, thus also serving as a call for planning and volunteer activity in the community.

The school operates a structured system of student exchanges with various academic institutions around the world and thus enables an international study experience and access to alternative study and planning approaches that receive academic recognition in the curriculum. In addition, the school holds annual exhibitions of the work of its graduates and of outstanding students from all study years, at central places in major cities. The exhibitions are curated, managed, produced, and constructed by the graduates independently, hence also affording them additional professional experience upon leaving for the professional and academic world of practice. These exhibits enable exposure of the school's activity and that of its students to the wide public and encourage discourse between them and the professional community as well as the public in general. These activities of the school emphasize the considerable significance it attributes to values embodied in the learning centered approach.

\section{About the Teaching Centered Paradigm and the Learning Centered Paradigm}

The vision of a global village is formed by means of the innovative networked technologies that make it possible to transfer varied information rapidly and to 
perform many operations in the global space, such as receiving news updates in real time, reading newspapers from any place in the world, ordering various services without leaving home, playing online games with other surfers, contacting other users in virtual forums and communities, working and studying from afar, and more (Barak \& King, 2000). Academe, by virtue of its responsibility for creating new knowledge in modern society, has also undergone a series of changes following the technological innovations and changes in society's values. The invention of the personal computer (Kulik, Kulik, \& Cohen, 1980), development of the global information network (BrckaLorenz, Haeger, Nailos, \& Rabourn, 2013; Jones, 2002), transition to distance learning (Phipps \& Merisotis, 1999), and the sharp rise in the number of students (although recently there is a considerable enrolment drop in universities around the world) are some of the factors that led to these changes. Despite the global changes and their impact on the world of higher education, there have been only slight changes in learning strategies and teaching methods in academe (Reynolds, 2000), despite the use of new technologies (McKeachie, 1990).

Notwithstanding the tremendous change in the status and accessibility of knowledge - particularly among students of higher education, who make frequent use of technology for learning purposes (BrckaLorenz et al., 2013) -teaching methods have remained constant and still focus mainly on transferring knowledge (Eberly, Newton, \& Wiggins, 2001). This fact is fairly problematic, as in this way the extensive operational use of technology in higher studies does not necessarily contribute to learning or teaching (Kazley et al., 2013). In other words, the academic environment changed as a result of technology, but most contemporary teaching methods (with the possible exception of computer enabled effects) have remained as previously.

This often leads to questions about the value of academic degrees and the quality of studies in academic classrooms, where teaching mostly continues to focus on transferring knowledge (Stage, Muller, Kinzie, \& Simmons, 1998). Many lecturers still think that they can transfer their knowledge in its complete form to students' minds. This is not only impossible, but in the information era it is an anachronistic approach that renders the lecturer irrelevant. Students often ask themselves (and the lecturers) why they should bother to come to class when all the material is on the course website or can be accessed freely on the web. Such questions express concerns as to what added value lecturers can give students beyond the transfer of knowledge.

These questions are relevant today more than ever and they constitute a challenge of the traditional paradigm of teaching courses in academe, i.e., "teaching-centered learning". Most of us were raised in this approach that sees the course as a place where teaching is transmitted by the study program (Barr \& Tagg, 1995). In a typical course, teaching is structured and transmitted based on the number of classes (duration of teaching in a semester and credits). Its purpose is to cover the course contents, and at its end students must perform a final assignment for assessment purposes (Reynolds, 2000). In the traditional teaching 
method, "teachers decide for the learner what is required from outside by defining characteristics of instruction, curriculum, assessment, and management to achieve desired learning outcomes" (Wagner \& McCombs, 1995: 32).

As a result of the learner's passivity as structured in teaching in the traditional approach, students take no responsibility and are not active partners in their learning process. They sit in class, take themselves from class to class, play with their smartphones, occasionally make a comment in class, enter Facebook, open their laptops, close their laptops. Eventually they finish the course with some knowledge but they themselves are no different essentially than they were to begin with. Students studying in the traditional approach do not truly acquire independent learning skills, and in this context it has been said that acquiring a Bachelor's degree is an empty achievement if in the process one does not acquire skills and capabilities appropriate for the twenty first century (Kuh, Kinzie, Schuh, \& Whitt, 2010). As stated, the purpose of the current article is to present a different approach to the act of teaching, while imparting applied tools for shifting from "teaching centered" instruction to "learning centered" instruction, in general and in architecture in particular.

\section{Learning-Centered Teaching}

Learning-centered teaching is a new-old educational paradigm (Seel, 2003) that has its roots in the rise of the progressive education movement in late $19^{\text {th }}$ century US. This approach is based on the principle that knowledge cannot be transferred to learners in its complete form, rather by causing learners to discover or acquire knowledge independently (Rogoff, 1994). This is a shift from the traditional approach that sees learning as a process of passive knowledge reception from a figure of authority to a learning-centered approach that sees learning as an active process in which learners go through a process of change (Gehart, 2011). While in the traditional approach the emphasis is on the scope and nature of contents learned, in the learning-centered approach the emphasis is on the nature of the learner's process. According to this outlook, learning is a variety of activities and programs that challenge students and give them an opportunity to grow (King \& Anderson, 2004). Growth occurs when students undergo a series of changes that lead them to more complex behavior, enabling them to cope with changing life challenges (Kuh et al., 1991). This approach is based on the premise that what students do is more important that what they learn in their undergraduate studies (Kuh et al., 2010).

The research literature shows that this approach indeed promotes higher quality learning of students. For example, a study examining the effect of learning-centered teaching versus instruction-centered teaching on the attitudes and knowledge of statistics students (Harpe, Phipps, \& Alowayesh, 2012) found that students in the learning-centered approach were more knowledgeable and had more positive attitudes toward their learning environment. Students in the learning-centered approach had more opportunities to use their knowledge and felt more in control of their grades. Nonetheless, despite the data supporting the 
learning-centered approach, most schools of higher education continue to treat information transfer as the most important value of teaching. Eberly, Newton, and Wiggins (2001) analyzed 145 syllabuses of various general undergraduate courses. Their thematic analysis found that $50 \%$ of syllabus themes dealt with administration (course format, course contents, and use of technology), while 75\% emphasized course development (basic information about the course, reading requirements, course contents, methods of assessment, and use of technology). Only one theme in all the syllabuses examined dealt with the interpersonal realm (accountability for learning). The researchers concluded that the main emphasis in courses is on transferring information, while the topic of developing skills or attitudes as part of learning receives almost no attention. They claim that the syllabus, as a meaningful tool in the learning process, must reflect and formulate the goals of the degree as well as the goals of the course.

The following is a comparison of the learning paradigm and the instruction paradigm (Barr and Tagg, 1995; Davidovitch, 2013) (Table 1).

\section{About Backward Course Design}

Constructing courses in a backward design is based on the premise that teachers must clarify to students unequivocally what they are expected to learn, do, and understand by the end of the lecture or course. Backward course design forces instructors to move the focus of course design from course contents to outcomes. Such a design makes it possible for instructors to answer the question often asked by students: "What are we doing this assignment? What is its purpose and will I ever use it in real life?” (Daugherty, 2006). Backward design answers three questions:

1) What will the student know and be able to do, by the end of the course, independent of the activities and texts we use?

2) What evidence should there be of such abilities?

3) Which sources, activities, and methods will best serve the desired results?

\section{Learning Outcomes}

The Bologna Process began in 1999 and formed the foundation for inter-country collaboration and for creating the European Higher Education Area (EHEA). The agreement stressed that mobility must become the identifying mark of the European Higher Education Area (Van der Hijden, 2012).

The purpose of the Bologna process is to enable academic mobility and to form uniform standards in higher education systems. This led to credentialism and meant a transition to the European Credit Transfer and Accumulation System (ECTS), in which each student can accumulate credits for a degree at any academic institution of his or her choice. Credit points are transferred to the parent institution and recognized towards the degree granted by the institution. This system of accumulation enables students to move between schools, experience learning in other places, and become familiar with varied study environments (Yemini \& Ben Artzi, 2013). 
Table 1. Comparison between the instruction and learning paradigms.

\begin{tabular}{|c|c|}
\hline The Learning Paradigm & The Instruction Paradigm \\
\hline \multicolumn{2}{|l|}{ Mission and Purposes } \\
\hline Produce learning & Provide instruction \\
\hline Encourage students to discover and construct knowledge & Transfer knowledge from lecturer to students \\
\hline Create a powerful learning environment & Offer courses and programs \\
\hline Improve the quality of learning & Improve the quality of instruction \\
\hline Achieve success for a wide range of students & Achieve access for a wide range of students \\
\hline \multicolumn{2}{|l|}{ Criteria for Success } \\
\hline Learning outcomes among students & Input, resources \\
\hline Quality of students completing the study unit & Quality of entering students \\
\hline Development of learning technologies & Development of the curriculum, expansion \\
\hline Quantity and quality of outcomes & Quantity and quality of resources \\
\hline Aggregate growth of learning and efficiency & Growth of enrolment \\
\hline Quality of students & Quality of faculty \\
\hline \multicolumn{2}{|l|}{ Teaching/Learning Structure } \\
\hline Holistic - whole prior to parts & Parts prior to whole \\
\hline Learning held constant, time varies & Time held constant, learning varies \\
\hline Learning held constant, time varies & $50 / 90$ minute lecture, course divided into study units \\
\hline Environment ready when student is & Classes start/end at a constant time \\
\hline Whatever the learning experience requires & One lecturer, one classroom \\
\hline Inter-disciplinary/departmental & Independent disciplines/departments \\
\hline Specific learning results & Covering material \\
\hline External evaluation of learning & Assessment by means of final assignment \\
\hline Public assessment & Private assessment \\
\hline Degree equals demonstrated knowledge and skills & Degree equals accumulated credits \\
\hline \multicolumn{2}{|l|}{ Learning Theory } \\
\hline Knowledge exists in each person's mind and is shaped by individual experience & Knowledge exists "out there" \\
\hline Knowledge is constructed, created & $\begin{array}{l}\text { Knowledge comes in pieces; delivered by instructors, } \\
\text { absorbed by students }\end{array}$ \\
\hline Learning progresses in a continuous holistic process & Leaning is cumulative and linear \\
\hline Learning is student centered and controlled & Learning is teacher centered and controlled \\
\hline The learning environment is cooperative and supportive & The learning environment is competitive and individualistic \\
\hline
\end{tabular}

Source: Davidovitch, 2013, p. 332.

The Bologna process offers several courses of action to help reach the targets determined. Use of learning outcomes, as well as course and curricula descriptions, have a major role in the process. For example, in 2003 it was decided in Berlin that European institutions of higher education would be required to describe qualifications in terms of learning outcomes. In this way the approach, 
based on learning outcomes, became more and more common around the world and in quality assessment processes of higher education institutions, including those in Israel. Notably, learning outcomes are the declarations of the lecturer/ group of lecturers that specify what the learners will know or will be expected to do as a result of the learning activity. Outcomes are usually manifested in the form of knowledge, skills, or attitudes, and they are statements on what students are expected to know, understand, and/or be capable of demonstrating by the end of the learning process (Botzer \& Barzilai, 2011).

\section{Backwards Course Design - From STEM Disciplines to All Academic Disciplines}

This approach was first adopted in the scientific disciplines, also known as STEM disciplines (science, technology, engineering, and mathematics). According to this approach, the point of departure is the end, i.e., course design should begin by clarifying the desired results, by formulating the outcomes that we expect to receive from the course (Wiggins \& McTighe, 2005). The STEM disciplines were the first to adopt this approach of using the course goals as the beginning point for planning the course (Steveler, Smith, \& Pilotte, 2012). Course planning was performed in four stages, in which the lecturer was required to map the desired outcomes, methods of assessment, and teaching strategies, as carefully as possible.

As stated, backward course design stems from the learning-centered paradigm, which rather than asking students "What did you learn in order to complete the course?" asks "What do you know and what can you do now that you could not do previously prior to taking this course?" Therefore, the first step in course design is defining instruction goals and outcomes: What will students know and be able to do, in general, by the end of the course? Once general goals have been defined, learning outcomes must be defined individually. The second step in course design is to decide what significant learning achievements should be achieved by learners. Then the third step is to choose a means of measuring achievement of the goals. Finally, only the fourth and final step includes deciding how to teach in order to achieve the intended learning outcomes.

Stage A: Formulating student-centered large goals in architecture studies, as an example of other academic fields

- What do you expect the graduate to know and be able to do?

- What do you expect the student to know and be able to do upon completing the course/unit? (Specifically with regard to skills, knowledge, proficiencies, perceptions, values)

- What is your vision? What effect do you want this course to have on students' life by the end of the course? In a few years?

- What are the practical expectations of course graduates?

According to the STEM approach, the possible goals are: ability to apply knowledge; ability to plan and conduct experiments; ability to analyze and interpret data; ability to function in teams; ability to identify, formulate, and solve 
architectural problems; understanding of professional and ethical responsibility; recognition of the need and the ability to continue learning throughout life; knowledge of current topics; ability to use current architectural methods, skills, and tools essential for present architectural work; ability to plan a system, component, or process in a manner that answers requirements in consideration of realistic constraints (financial, environmental, social, political, ethical constraints); ability to efficiently impart the wide education necessary in order to understand the effect of solutions in the local, regional, global, environmental, cultural, and social context.

Stage B: Formulation of operative (executive) aims resulting from the large goals

In this stage 3 - 5 behavioral aims shall be formulated, listing anticipated academic outcomes from the perspective of learners. For example: by the end of the course the student shall be able to: identify and solve relevant problems, choose the most suitable way of solving them, according to the features of each problem, understand the characteristics of the solution method, and correctly interpret the results.

Stage C: Choosing assessment methods (for measuring achievement of teaching goals) and setting criteria for assessing performance: How can students demonstrate that they know and are capable of doing what is expressed in the goals?

There are varied modes of assessment: presenting a personal or group project before the class and the instructors; peer assessment from within the school or from elsewhere; self-assessment; written tests and quizzes; oral tests; open-ended or closed (multiple-choice) tests; authentic assignments; homework or personal or group project.

Stage D: Choosing teaching methods/strategies for achieving aims: What will you do in your teaching so that students can achieve the aims you formulated?

There is a wide range of approaches to teaching. For example: lectures; seminars; exercise classes; laboratories and studios. There is also a wide range of activities, for example: discussions; demonstrations; practice/exercise; joint work in pairs, teams, and groups; learning based on precedents and case studies; technology supported learning, and more.

In each method, secondary aims should be listed as well as the enriching learning experiences that it will include. For example, if the goal of instruction is "the teaching and learning methods will help students develop skills, both in teamwork and in individual work," then teaching methods for achieving the secondary aims of this goal might be:

- In order to learn how to work in a team, students will be required to work in a group.

- In order to learn to communicate, assignments on communication problems will be given.

- In order to instill taking responsibility for learning, students will learn inde- 
pendently how to perform assignments.

- In order to learn ethical, social, professional, and environmental aspects related to the discipline, appropriate examples for demonstration and discussion will be included.

\section{Discussion on the Learning Outcomes of the Architectural Studio}

\subsection{Group Guidance}

The process of guidance in the studio is based on the dialogue that develops between the instructor and the student or group of students in the form of discussion and conversation, unlike frontal lectures.

In this process, illustrations and clarification of intentions by both the instructor and the student/s, are important:

1) It is important to base one's words on examples, precedents, and means of illustration.

2) It is necessary to give clear instructions as to each stage of execution of the project and its presentation.

3) Documentation of the process by the instructor and the students, to help handle difficulties and communication discrepancies that arise during guidance and that affect the quality of learning.

\subsection{Examples of Formulating Learning Outcomes in the Studio}

1) Definition of teaching goals: What shall the student know and be capable of doing in general by the end of the course? Formulating general student-centered goals.

Upon successfully completing the course the student will be able to:

- Present a design solution through graphic means, three-dimensional models, computerized simulations, verbal demonstration and supportive documentation, which will also provide the basis for future development to the stage of implementation.

- Combine aesthetic, scientific, cultural, legal, political, economic, social, ecological, and technological considerations when solving problems related to the planning or management of sustainable places.

- Complete a process of architectural planning in various fields, such as: residential, public buildings, mixed use structures, environmental and landscape planning, interior architecture, urban planning and design, and more, combining theoretical knowledge and a research approach to the selected topic.

- Document an existing site, analyze it, and form an idea for architectural intervention in the site.

2) How can teaching be affected in order to achieve the intended learning outcomes? Choosing teaching methods/strategies for achieving the goals.

The purpose: to develop the student's skills of working both independently and in a team. Suitable teaching methods are:

- Learning to function in a team - Group work is essential. 
- Being capable of communicating and demonstrating visually and verbally Communication assignments should be given.

- Learning how to learn and accept responsibility for their learning - Students should be given suitable assignments for self study and for solving problems throughout their studies.

- Understanding and internalizing ethical, social, environmental, and professional subjects - It is necessary to include suitable examples for illustration and discussion.

3) Individual definition of learning outcomes: What are the significant learning achievements that the learners will achieve? Formulation of individual goals (behavioral aims) for achieving the general goals.

What will you do in your instruction and teaching so that the students will be able to achieve the aims you formulated? What will be the activities? For example: discussion, demonstration, practice/exercise, work in pairs/groups/ collaborative, learning based on cases/problem solution, technology-supported learning. Other experiences?

4) How can they be measured at the end of the course? Choosing methods for assessing achievement of individual goals.

\section{How Can the Learning Outcomes be Measured - Assessment}

Formative assessment: Performed at the beginning and during the course, provides information on students' progress, refers to activities undertaken by the teacher or the student (self assessment), in order to provide information to help better plan further teaching and learning, provides effective feedback in real time, lets the lecturer/instructor respond to students' needs, with the aim of improving learning.

Summative assessment summarizes the student's learning at a certain point in time, usually performed at the end of the course, with the aim of describing achievements.

Interim assessment combines the formative and the summative assessments.

Assessment strategy by expected learning outcomes:

Students who successfully complete their studies will be able to demonstrate:

- Visual frontal presentation and speech skills: the ability to listen and speak in a clear, focused, and efficient manner, and to present the appropriate visual material concurrently.

- Critical thinking skills: the ability to raise relevant, clear, and accurate questions, to use abstract ideas in order to interpret information, to consider different perspectives, to reach justified conclusions, and to examine them by appropriate acceptable criteria and standards.

- Visual communication skills: the ability to use a suitable representation media, including free hand sketching, in addition to use of computer technology and three-dimensional models; the ability to present essential formal elements at every stage of the planning process.

- Research capacities: the ability to gather, evaluate, record, and implement re- 
levant research information when working on architectural courses.

- Formal ordering systems: understanding the foundations of visual perception and the principle of order that affect two-dimensional and three-dimensional design in the architectural and urban composition.

- Basic planning skills: the ability to use basic architectural principles in planning sites, buildings, and external and internal spaces.

- Skill sharing: the ability to identify a team's diverse talents in an interdisciplinary planning project, in professional and academic practice, and to work in collaboration with other students as part of a planning team.

- Traditions: understanding the rules and traditions of architecture and the traditions of planning urban landscape and design, as well as climate, technology, economic, cultural, and social elements and, other elements that shape and maintain them.

- Use of precedents: the ability to combine relevant precedents in architectural and urban projects.

- Human behavior: understanding investigative methods and theories that seek to clarify the relationship between human behavior and the physical environment.

- Human diversity: understanding the diverse needs, values, behavior norms, physical abilities, and social and spatial patterns characteristic of the cultures and people, and the implications of this diversity for the social roles and responsibilities of the architectural discipline.

- Accessibility: the ability to design the site and the structure in a manner adapted for housing people with various physical and mental handicaps.

- Sustainable planning: understanding sustainability principles in architectural and design decision making and urban planning that preserve and develop natural and built resources, including structures and sites, from a cultural aspect, and in creating good and healthy communities and structures.

\section{Assessment Criteria}

- Are learning outcomes measurable and how? Can they be assessed?

- Can the outcomes be achieved in the given time frame and resources and how?

- Do the learning outcomes derive from the goals of the program? Of the course?

- Is the formulation clear? Lucid? Unambiguous while also enabling conceptual pluralism?

- Are the learning outcomes written in terms of performance? Do the learning outcomes describe what learners will be able to do upon successfully completing the learning process?

The uniqueness of the teaching and learning method begins with identification of the course learning goals rather than with the course material and contents. How are goals identified? The lecturer asks oneself: What must students know and be capable of doing by the end of the course? 
Choosing assessment methods and determining criteria for assessing performance according to the goals.

Choosing the manner of teaching and learning according to the goals: What is my best teaching technique as lecturer in order to achieve the learning goals, both regarding the material included in the course and regarding the teaching and learning strategy, planning the schedule, and designing the syllabus.

\section{Summary of the Advantages of Teaching Based on Learning Outcomes}

Learning outcomes help lecturers: clearly define for students what is expected of them; plan the materials more efficiently by using them as a pattern; choose the appropriate teaching strategy; plan the curriculum by clarifying congruent and supplementary areas between courses; comprehensively and precisely define what students will be capable of achieving by the end of their studies.

Learning outcomes help students: learn in a more efficient and collaborative way: students know where they are situated, they become partners in the study process and involved in its application and thus the study program becomes more accessible and user friendly; choose courses; helps external factors: information for academic agents, employers, and institutions of higher education about the nature of the course and students' achievements; contribute to students' mobility by assisting with recognition and assessment.

Assessment of performance: A teaching strategy based on assessment of student performance on assignments in academic courses following the SWOT model.

The purpose: Lecturers (and students) strive to improve students' performance on assignments and assess the performance in a way that will promote students' learning.

The way: use of a teaching strategy based on providing feedback to students on performance of assignments during the course. The feedback will be given by peers, by the lecturer, and through class discussion.

Such teaching is based on the SWOT (strengths, weaknesses, opportunities, threats) model.

When: The teaching strategy is applicable in any course in which students are required to submit a given performance product (model, product, project) as their assignment.

\section{Adoption of the Model as a Method of Assessment in Academic Courses}

The SWOT model refers to academic course requirements and includes:

- Strengths - Identification and evaluation of strengths, abilities, and positive states of the presented assignment, intended to let students realize achievement of their goals;

- Weaknesses - Identification and evaluation of inabilities and situations that might prevent students from achieving their desired goals; 
- Opportunities - Identification and evaluation of factors and situations that can help students achieve their goals, but have not yet been utilized by them in the product presented;

- Threats - Presenting alternatives and operative suggestions for the required improvement, with regard to weaknesses and/or opportunities not yet utilized by students.

\section{Discussion}

The unique role of the backward design instruction method according to the learning centered approach is evident in its commencing with identification of the learning goals of the course rather than with the course material and contents. In order to identify the goals, instructors must ask themselves what students must know and be able to do by the end of the course. Then they must choose assessment methods and standards for measuring implementation. According to the goals defined, a teaching and learning method shall be chosen. Instructors must choose the best teaching method for them as teachers and for the relevant students, both regarding the material to be included in the course and regarding the instruction strategy, planning of the schedule, and syllabus design. Expanding use of the backward design approach, in the learning centered approach, to all academic disciplines shall enable students to personally benefit from a wide array of courses rather than only STEM courses. If course design will continue to utilize a content-centered approach, many disciplines will probably become irrelevant, and students will continue to leave as they arrived, with no added skills and knowledge.

With the gradual increase in accessible knowledge, instructors are required to bring with them added value to the learning. This is a complicated requirement that compels instructors to think "outside the box" and relinquish regular teaching patterns. Planning a course in this method undoubtedly requires extensive thinking, time, and effort, compared to designing a course in the traditional method. It requires one to become acquainted with students, be prepared for changes, and plan each lesson. In the backward design approach, there is no room for mere spontaneity. An instructor cannot come to class without selfexamination of the goals and means to be used, and without being prepared to listen to students' opinion and to demonstrate openness and flexibility to development of the lesson according to the developing learning dialogue. This requires a big effort, however, such an effort makes it possible for the instructor to face students with a real honest answer to questions such as "How will this help me in life?" or "Why should I come to class?"

Nevertheless, the instructor's efforts are not enough. In order for deep meaningful change to occur in how instructors teach in academe, this must be reinforced by policymakers. In an academic environment where instructors' output equals the number of their scientific publications (= research output), instructors have no incentive to make an effort and develop their teaching. The Council for Higher Education (CHE) also recognizes the significance of incentives to 
produce teaching outcomes. However in the council's budgeting model, teaching output relates mainly to the number of undergraduate and graduate students in the school and to the level of degrees awarded, calculated in an efficiency formula (Council for Higher Education, 2012). Despite the change in the budgeting model employed by the CHE, from its conception until the new model was applied in 2011 (ibid., pp. 20-33), it is doubtful whether this can undermine the superior status of the research component and motivate faculty to see efficient teaching as a type of academic output worthy of significant academic recognition as well.

\section{Conclusion}

There is an urgent need to establish the learning-centered approach as the main teaching method in a wide range of faculties in traditional universities in order to reinforce the universities' main advantage over a learning approach that privilegizes virtual means of knowledge acquisition and virtual academic centers, and also in order to maintain their relevancy and appeal for current students, as well as for future applicants to higher education.

To establish the learning-centered approach as the primary method of teaching, academic institutions also need a model that recognizes, appreciates, and compensates for the faculty's efforts at learning-centered teaching, and one that will urge instructors to devote time and energy to developing and upgrading their teaching to develop these aspects in their work. This is also in the existential interest of the institutions of higher education, as entities also responsible for properly training the next generations, in an era when traditional teaching methods being no longer sufficient, not attractive, and no longer answering the needs and wishes of potential students for shaping their personal and professional future, in light of the paradigmatic changes in knowledge acquisition in the "global village".

The main contribution of this research is the raise the awareness of academic teachers and lecturers, as well as higher education policy and decision makers, of the urgent need today to reconsider teaching methods in the universities. Detailed methods and incentives to persuade academic faculty to adopt the learning-centered approach, and the methods to ensure that they are aware that such a change is crucial for the future existence of their institutions, remain to be explored in further research.

\section{References}

Amaral, A., \& Magalhães, A. (2004). Epidemiology and the Bologna Saga. Higher Education, 48, 79-100. https://doi.org/10.1023/B:HIGH.0000033766.02802.92

Barak, A., \& King, S. A. (2000). The Two Faces of the Internet: Introduction to the Special Issue on the Internet and Sexuality. Cyber Psychology \& Behavior, 3, 517-520.

https://doi.org/10.1089/109493100420133

Bar-El, A., \& Nuemayer, M. (1996). Encounters with Psychology(2nd ed.). Tel Aviv: Rechess.

Barr, R. B., \& Tagg, J. (1995). From Teaching to Learning-A New Paradigm for Under- 
graduate Education. Change, 27, 13-26.

https://doi.org/10.1080/00091383.1995.10544672

Bills, D. B. (2004). Creeping Credentialism in the Unites States and Germany: Changing Relationships between Educational Credentials and Occupational Assignment. www.iuperj.br/rc28/papers/bills\%20rc28\%20brazil\%20hiring\%trends.pdf

BrckaLorenz, A., Haeger, H., Nailos, J., \& Rabourn, K. (2013). Student Perspectives on the Importance and Use of Technology in Learning. Paper presented at the Annual Forum of the Association for Institutional Research, Long Beach, CA, 18-22 May 2013. http://cpr.iub.edu/uploads/NSSE13\%20AIR\%20Technology\%20Paper.pdf

Brown, D. K. (2001). The Social Sources of Educational Credentialism: Status Cultures, Labor Markets, and Organizations. Sociology of Education, 74, 19-34.

https://doi.org/10.2307/2673251

Canny, A. (1995). School-Leavers' Career Choices: An Investigation of the Relationship between Action and Structure. Irish Journal of Sociology, 5, 164-191. https://doi.org/10.1177/079160359500500108

Cassidy, T., \& Lynn, R. (1991). Achievement Motivation, Educational Attainment, Cycles of Disadvantage and Social Competence: Some Longitudinal Data. British Journal of Educational Psychology, 61, 1-12. https://doi.org/10.1111/j.2044-8279.1991.tb00956.x

Council for Higher Education (2012). Budgeting Model of Israel's Higher Education System (pp. 20-33). Jerusalem: Planning and Budgeting Committee. (In Hebrew)

Daugherty, K. K. (2006). Backward Course Design: Making the End the Beginning. American Journal of Pharmaceutical Education, 70, Article 135. https://doi.org/10.5688/aj7006135

Davidovitch, N. (2013). Learning-Centered Teaching and Backward Course DesignFrom Transferring Knowledge to Teaching Skills. Journal of International Education Research, 9, 329-338. https://doi.org/10.19030/jier.v9i4.8084

Dippelhofer-Steim, T., Bargel, B., Bromberek, E., Jetten, S., Kump, G., Sagmeister, H.-G., \& Walter, J. T. (1984). Students in Europe, Motives for Studying, Expectations of Higher Education and the Relevance of Career Prospects. European Journal of Education, 19, 309-315. https://doi.org/10.2307/1502848

Dore, R. (1976). The Diploma Disease: Education, Qualification and Development. London: George Allen \& Unwin.

Doron, N. (1983). On the Path to Success. Tel Aviv: Yahdav Publishing.

Eberly, M. B., Newton, S. E., \& Wiggins, R. A. (2001). The Syllabus as a Tool for Student-Centered Learning. The Journal of General Education, 50, 56-74. https://doi.org/10.1353/jge.2001.0003

Gehart, D. (2011). The Core Competencies and MFT Education: Practical Aspects of Transitioning to a Learning-Centered, Outcome-Based Pedagogy. Journal of Marital and Family Therapy, 37, 344-354. https://doi.org/10.1111/j.1752-0606.2010.00205.x

Greene, H., \& Minton, R. (1989). Beyond the Ivy Wall: 10 Essential Steps to Graduate School Admission. Boston, MA: Little Brown \& Company.

Harpe, S. E., Phipps, L. B., \& Alowayesh, M. S. (2012). Effects of a Learning-Centered Approach to Assessment on Students' Attitudes towards and Knowledge of Statistics. Currents in Pharmacy Teaching and Learning, 4, 247-255. https://doi.org/10.1016/j.cptl.2012.05.002

Jones, S. (2002). The Internet Goes to College: How Students Are Living in the Future with Today's Technology. Pew Internet \& American Life Project. http://files.eric.ed.gov/fulltext/ED472669.pdf

Kazley, A. S., Annan, D. L., Carson, N. E., Freeland, M., Hodge, A. B., Seif, G. A., \& 
Zoller, J. S. (2013). Understanding the Use of Educational Technology among Faculty, Staff, and Students at a Medical University. TechTrends, 57, 63-70. https://doi.org/10.1007/s11528-013-0647-Z

King, J. M., \& Anderson, D. M. (2004). A Practitioner's Guide to a Learning-Centered Co-Curricular Activities Program. College Student Affairs Journal, 24, 91-100.

Kuh, G. D., Kinzie, J., Schuh, J. H., \& Whitt, E. J. (2010). Student Success in College: Creating Conditions that Matter. San Francisco, CA: Jossey-Bass.

Kuh, G. D., Schuh, J., Whitt, E., Andreas, R. E., Lyons, J. W., \& Strange, C. C. (1991). Involving Colleges-Successful Approaches to Fostering Student Learning \& Development outside the Classroom. San Francisco, CA: Jossey-Bass.

Kulik, J. A., Kulik, C.-L. C., \& Cohen, P. (1980). Effectiveness of Computer-Based College Teaching: A Meta-Analysis of Findings. Review of Educational Research, 50, 525-544. https://doi.org/10.3102/00346543050004525

McKeachie, W. J. (1990). Research on College Teaching: The Historical Background. Journal of Educational Psychology, 82, 189-200.

https://doi.org/10.1037/0022-0663.82.2.189

Phipps, R., \& Merisotis, J. (1999). What's the Difference? A Review of Contemporary Research on the Effectiveness of Distance Learning in Higher Education. Washington DC: Institute for Higher Education Policy.

Reynolds, J. (2000). Learning-Centered Learning: Theory into Practice. Inquiry, 5, 1-9.

Rogoff, B. (1994). Developing Understanding of the Idea of Communities of Learners. Mind, Culture, and Activity, 1, 209-229.

Seel, N. M. (2003). Model-Centered Learning and Instruction. Technology, Instruction, Cognition and Learning, 1, 59-85.

Shapira, R., \& Etzioni, E. (1973). Who Is the Israeli Student? Tel Aviv: Sifriyat Ofakim, Am Oved. (In Hebrew)

Stage, F. K., Muller, P. A., Kinzie, J., \& Simmons, A. (1998). Creating Learning Centered Classrooms. What Does Learning Theory Have to Say? ERIC Digest.

http://www.ydae.purdue.edu/lct/hbcu/documents/Creating_Learning_Centered_Classr ooms_What_Does_Theory_Say.pdf

Streveler, R. A., Smith, K. A., \& Pilotte, M. (2012). Aligning Course Content, Assessment, and Delivery: Creating a Context for Outcome-Based Education. In K. Mohd Yusof, S. Mohammad, N. Ahmad Azli, M. Noor Hassan, A. Kosnin, \& S.K. Syed Yusof (Eds.), Outcome-Based Education and Engineering Curriculum: Evaluation, Assessment and Accreditation (pp. 1-26). Hershey, PA: IGI Global.

Tyler, W. (1982). Complexity and Control: The Organisational Background of Credentialism. British Journal of Sociology of Education, 3, 160-170.

https://doi.org/10.1080/0142569820030204

Van der Hijden, P. (2012). Student Mobility in Europe: Recent Trends and Implications of Fata. In: P. Scott, L. Vlasceanu, \& L. Wilson (Eds.), European Higher Education at the Crossroads: Between the Bologna Process and National Reforms (pp. 377-386). Netherlands: Springer.

Vedder, R. (2011). Too Many PhDs and Professionals? The Chronicle of Higher Education. 5 January 2011.

https://chronicle.com/blogs/innovations/too-many-ph-d-\%E2\%80\%99s-and-professio nals/28236

Vernon, J. (2010). Disaster Strikes: The End of the Public University in England. Universities in Crisis, Blog of International Sociological Association (ISA). [Blog post], 22 October 2010. http://www.isa-sociology.org/universities-in-crisis/?p=774 
Wagner, E. B., \& McCombs, B. L. (1995). Learner Centered Psychological Principles in Practice: Designs for Distance Education. Educational Technology, 35, 32-35.

Wiggins, G., \& McTighe, J. (2005). Understanding by Design: Expanded Second Edition (pp. 140-142). Alexandria, VA: ASCD.

Windolf, P. (1995). Selection and Self-Selection at German Mass Universities. Oxford Review of Education, 21, 207-231. https://doi.org/10.1080/0305498950210206

Wonacott, M. E. (2000). Credentials: One Size Fits All? Columbus, OH: National Dissemination Center for Career and Technical Education. ED 447275.

Yemini, M., \& Ben-Artzi, Y. (2013). Application of the Bologna Process in Israel's System of Higher Education. Dapim, 55, 177-197. (In Hebrew)

Submit or recommend next manuscript to SCIRP and we will provide best service for you:

Accepting pre-submission inquiries through Email, Facebook, LinkedIn, Twitter, etc. A wide selection of journals (inclusive of 9 subjects, more than 200 journals)

Providing 24-hour high-quality service

User-friendly online submission system

Fair and swift peer-review system

Efficient typesetting and proofreading procedure

Display of the result of downloads and visits, as well as the number of cited articles

Maximum dissemination of your research work

Submit your manuscript at: http://papersubmission.scirp.org/

Or contact ce@scirp.org 